Bartın Üniversitesi İktisadi ve İdari Bilimler Fakültesi Dergisi,

2021, Cilt 12, Sayı 23

Bartın University Journal of Faculty of Economics and Administrative Sciences,

2021, Volume 12, Issue 23

E-ISSN: 2148-2497

http://iibfdergi.bartin.edu.tr/

https://dergipark.org.tr/tr/pub/bartiniibf

Derleme Makale, Gönderim Tarihi: 16.05.2021; Kabul Tarihi: 27.05.2021

\title{
A Promising Opportunity for the Integration of Syrian Refugees in Turkey: New Targets in Accessing the Labor Market through Vocational Education and Training
}

\author{
Prof. Dr. Mahmut ÖZER \\ Milli Eğitim Bakanlı̆̆ \\ mahmutozer2002@yahoo.com, Orcid ID: 0000-0001-8722-8670
}

\begin{abstract}
In recent years, the wars across the world have dramatically increased the demographic mobility among countries. Particularly, the Syrian civil war led to the displacement of millions of people within Syria and also caused the leave of Syrians from their country. The responsibilities of neighboring countries have increased considerably. Turkey, which has been implementing 'open-door diplomacy' since 2011, is the country hosting the highest number of refugees in the world as of 2021. This study evaluates Syrian refugees' access to vocational education and training (VET) in Turkey. In this context, the importance of policies to increase access to vocational training centers (VTCs), which have a major potential in facilitating their transition to the labor market and supporting their social integration, is highlighted. In addition, new steps taken by the Ministry of National Education (MoNE) towards the integration of Syrian migrants are discussed.
\end{abstract}

Keywords: Syrian refugees, vocational education and training, integration, labor market

JEL Classification: H52, I24, I25

APA: Özer, M. (2021). Promising Opportunity for the Integration of Syrian Refugees in Turkey: New Targets in Accessing the Labor Market through Vocational Education and Training. Bartın Unıversity Journal of Faculty of Economics and Administrative Sciences, 12 (23), 239-251.

APA: Özer, M. (2021). Suriyeli Göçmenlerin Entegrasyonu İçin Önemli Bir İmkân: Mesleki Eğitim Üzerinden İşgücü Piyasasına Erişimde Yeni Hedefler. Bartın Üniversitesi İktisadi ve İdari Bilimler Fakültesi Dergisi, 12 (23), 239-251. 


\title{
Türkiye’de Suriyeli Göçmenlerin Entegrasyonu İçin Önemli Bir İmkân: Mesleki Ĕgitim Üzerinden İşgücü Piyasasına Erişimde Yeni Hedefler
}

\author{
$\ddot{\mathbf{O} z}$
}

Dünyada son yıllarda yaşanan savaşlar ülkeler arasında demografik hareketliliği çok dramatik bir şekilde artırmıştır. Bu bağlamda Suriye iç savaşı milyonlarca insanın Suriye içerisinde yer değiştirmesine yol açarken bir o kadar da Suriyelinin ülkelerini terk etmelerine yol açmıştır. Elbette bu süreçte komşu ülkelere düşen sorumluluklar oldukça artmıştır. 2011 yılından itibaren 'açık-kapı diplomasisi' uygulayan Türkiye, 2021 y1lı itibariyle dünyada en fazla göçmene ev sahipliği yapan ülke konumundadır. $\mathrm{Bu}$ çalışmada Suriyeli göçmenlerin mesleki eğitime erişim durumları değerlendirilmektedir. Bu bağlamda, işgücü piyasalarına geçişlerini kolaylaştırmada ve toplumsal entegrasyonlarını güçlendirmede önemli potansiyele sahip mesleki eğitim merkezlerine erişimi artırmaya yönelik geliştirilecek politikaların önemine vurguda bulunulmaktadır. Ayrıca, Milli Eğitim Bakanlığı tarafından Suriyeli göçmenlerin entegrasyonuna yönelik atılan yeni adımlar değerlendirilmektedir.

Anahtar Kelimeler: Suriyeli göçmenler, mesleki eğitim, entegrasyon, işgücü piyasası

JEL Sinıflandırması: H52, I24, I25

\section{Introduction}

In recent years, there has been a remarkable increase in the number of people forced to leave their country due to wars and violence. The increase has heaved in sight in demographic mobility, increasing from 33.9 million in 1997 to 68.5 million in 2017 (UNHCR, 2017). One of the major reasons for the increase is the Syrian civil war (Cantekin, 2019). One of the greatest demographic movements of the century was experienced with the start of the war in 2011. Turkey has demonstrated the most humanitarian approach and has opened the borders to Syrians who are victims of war with its 'Open-Door Policy'. Additionally, Turkey has conducted comprehensive projects to increase their access to health, education and fundamental humanitarian services. Currently, Turkey is the country hosting the highest number of refugees in the world, with a population of approximately four million (Adalı \& Türkyılmaz, 2020; Cantekin, 2019). The age interval of Syrian refugees is comparatively quite young, and it is critically important for education and access to the labor market in the long term (Adalı \& Türkyılmaz, 2020).

Education is particularly important in the structural integration of refugees (Koehler \& Schneider, 2019). In this context, the education needs of Syrians, who initially lived in camps in border provinces in Turkey, were met in the camps. For this 

İşü̈cü Piyasasına Erișimde Yeni Hedefler

purpose, temporary education centers (TECs) were established in the camps, and education was provided in Arabic language and based on Syrian curriculum in order to facilitate their adaptation to Syria after the war period. In fact, this approach represents the first phase of refugee education policies in Turkey and is mostly based on the prediction that the war will end in a short time and Syrian refugees will return to their countries (Emin, 2016). However, this prediction became inaccurate as time passed, and revisions in refugee education policies have become inevitable (Unutulmaz, 2017, 2019). The Turkish language courses are also included in TECs program in addition to Arabic language, and the curriculum is revised without a major change in its structure.

Meanwhile, the mobility of Syrian refugees towards out of the camps has increased. Movements have started to increase, especially towards the provinces where the labor market provides more potential for employment. TECs have also become more widespread outside the refugee camps and in different provinces of Turkey. For example, while only 36 of the 425 TECs in 21 provinces located in camps in 2017, the vast majority of TECs provided educational services outside of the camps (Unutulmaz, 2019).

As the war maintains its effect in Syria, education policies in Turkey evolved from temporary approaches to the permanent solutions (Bircan \& Sunata, 2015; Emin, 2016). As the number of Syrians and their duration of stay increased, the necessity of new regulations has emerged. Consequently, Syrian refugees have been taken under temporary protection with the Foreigners and International Protection Law No. 6458 which was published in the Official Gazette (11 April 2013, no. 28615). The educational services for Syrian children were revised comprehensively through the circular titled 'Education and Training Services for Foreigners' (no. 2014/21) and published by the MoNE in 2014. Based on this regulation, Syrian children were enabled to enroll in Turkish public schools in addition to TECs. After 2016, TECs were expected to be closed over a three-year period without new registration based on the purpose of full integration of Syrian refugees with the Turkish formal education system (Unutulmaz, 2019). After this stage, the enrollment of Syrian refugees in Turkish public schools at all levels has remarkably increased. TECs have been closed by the end of 2020 .

MoNE has taken important steps to facilitate the integration of Syrian children into the education system after the regulation in 2016. Firstly, the "Project on Promoting Integration of Syrian Kids into the Turkish Education System" (PIKTES) was initiated in cooperation with the European Union (EU) (Dolapcioğlu \& Bolat, 2019; Tüzün, 2017). Within the scope of the project, Syrian children in school-age are supported with Turkish and Arabic language. Additionally, they are provided remedial education for basic skill deficiencies, transportation for education, psychosocial support, and educational materials free of charge (Sarmini, Topçu, \& Scharbrodt, 2020). Thus, Syrian children were supported comprehensively to facilitate their transition to Turkish public schools. These policies have yielded positive results, and the enrollment rate of 
Syrian children to primary education has increased over time (Emin, 2016, 2019). MoNE currently continues the PIKTES project, which aims to integrate Syrian children into the education system.

On the other side, vocational education and training (VET) is not adequately highlighted in the integration of Syrians into the Turkish education system. In this regard, Germany has made significant improvements in social integration of immigrants through the advantages of dual VET system (OECD, 2017; Stoewe, 2018; Tanrikulu, 2020). Based on this approach, Germany both supports the integration of immigrants, and also tries to meet the human resource need of its labor market (Hindy, 2018). The first steps considering the advantages of VET for immigrants' integration have started to be taken in the 2020s in Turkey. This study evaluates the level of Syrians' access to VET within transition of refugees to public schools after 2016, and the potential of VTCs offering dual VET and significant opportunities for participation to the labor market as in Germany. Based on discussions, suggestions for improving the refugees' integration through VET are made.

\section{Vocational Education and Training in Turkey}

As it extends a long time and tradition, VET has a major role in secondary education in Turkey. VET in secondary education is offered through two options in Turkey: Vocational and Technical Anatolian Highschools (VTAHs) and Vocational Training Centers (VTCs). Both options cover four-year education, while the VET program is more academic and theoretical in VTAHs, it is more practical based in VTCs. On-the-job training is provided one day a week at school and other days in companies in VTCs (Özer, 2018, 2019a, 2019b). Therefore, VTCs combine on-the-job training in schools and companies, mostly similar to the dual VET system in Germany. VTC also covers the traditional apprenticeship, journeyman and mastership programs. While the number of students studying in VET at secondary education level is around 1.5 million in Turkey, about $10 \%$ of VET students in VTCs.

The programs in VTCs differ significantly from those in VTAHs in terms of age flexibility in enrollment and support provided during the education (Özer, 2018). First of all, VTCs do not only address the high school age population including secondary school graduates, but are also accessible to adults. On the other hand, students enrolled in VTCs receive one third of the minimum wage and are insured against occupational diseases within the scope of occupational health and safety for four years (during their education period). Therefore, VTCs are accepted as a successful model in raising the human resources needed by local labor markets with its opportunities through active participation of the sectors. Employment rates of VTC students also show appreciation of the model: $88 \%$ of graduates are employed in their field of education, while $75 \%$ of them are employed in companies where they have been trained for four years. 
Türkiye'de Suriyeli Göçmenlerin Entegrasyonu İçin Önemli Bir İmkân: Mesleki Eğitim Üzerinden İssücü Piyasasına Erișimde Yeni Hedefler

Concrete steps have been taken for years to increase access to VET and reduce youth unemployment by facilitating the transition to the labor market in Turkey. Since the end of 2018, these steps have been planned and implemented in a more systematic way. The training programs in all available vocational fields have been updated in line with the demands of the labor market and aligned with national occupational standards (Canbal et al, 2020). The collaborations have been enhanced with the sectors in all vocational fields and the active participation of sector representatives in all aspects of VET has been promoted and ensured. The scholarship opportunities for students have been enriched in order to increase the attractiveness of VET among students. These systematic steps have started to be productive in a short time, and the number of students who take vocational track has been constantly increasing (Özer \& Suna, 2019). Moreover, the preference of academically high-performing students towards VET has increased remarkably, and students from the top percentiles (top \%1) have started to prefer VET programs in the last three years. In order to alleviate the skill mismatches in the labor market, new regulations have been made in order to balance the supply and demand in VET on a rational basis, and to increase the matching of VET high schools and institutions with the sector needs (Özer \& Suna, 2020; Suna et al, 2020).

MoNE has attached a particular attention to on-the-job training in order to strengthen the cycle of education-production-employment in VET and supported the productions of students within this scope. In 2020, the amount of production made within this scope of VET has increased 100\%. MoNE also established 43 R\&D centers in VET institutions and focused on the production of patents, utility models, designs and brands within the scope of intellectual property. These improvements have led to a sixfold increase in the number of registered products compared to previous years (Özer, 2021a). The improved production capacity of VET contributed to production of materials such as masks, disinfectants, and face protective shields at the beginning of the Covid-19 pandemic, enabling them to deliver the required areas in a short time in 81 provinces of Turkey (Özer, 2020a, 2020b, 2020c). The production within the scope of VET was not only limited to these products, but it was also able to produce highly complex products from mask machines to respirators.

As a result, the improvements in the VET system have contributed a lot to meet the human resources needed by the labor market with all required standards (Özer, 2020d, 2020e). MoNE constantly conducts new projects to further improve the quality of VET (Özer, 2021a, 2021b; Özer, Gençoğlu, \& Suna, 2020). Therefore, the opportunities offered by VET and the potential to reduce youth unemployment also create an important opportunity for the integration of Syrian refugees. Below, the potential of VET for the integration of Syrian refugees is discussed. 
A Promising Opportunity for the Integration of Syrian Refugees in Turkey: New Targets in Accessing the Labor Market through Vocational Education and Training

\section{Syrian Refugees' Access to Vocational Education and Training}

VET is one of the mostly used instruments in the integration of immigrants into their new country. Through the active use of VET, immigrants can participate in the labor market in a relatively short time and their employability increases. On the other hand, the schooling rates of immigrants seem to decrease in further levels of education in most countries. The reasons and suggestions for this problem are beyond the scope of this study. Therefore, VET leads to an important opportunity for social integration for immigrants who do not attend the advanced levels of education. A major problem of migrants who are outside the school age population is that they are obliged to work informally in the labor market (Del Carpio \& Wagner, 2015; Siviş, 2020). In this case, they mostly work in inadequate conditions with low wages and without health insurance, and these lead to social disharmony. Therefore, access of immigrants to VET has a critical function especially for this age group.

The first comprehensive step regarding Syrians' participation in the education and labor market in Turkey was taken in 2016. Within this scope, it has been decided to close the TECs gradually and the collective integration of Syrian refugees to the Turkish education system was aimed. On the other hand, a new regulation for the legal participation of refugees' under temporary protection in the labor market in 2016 creates a legal framework for the participation of refugees in the labor market. This regulation is a comprehensive step towards the employment of Syrians in the labor market. Therefore, both steps have revealed the potential of VET for the integration of Syrians through its relation to the labor market. However, the potential of VET for the integration of refugees cannot be used adequately in Turkey (Şimşek, 2019; Tanrıkulu, 2020).

While the Syrians' interest towards VET has stayed at a similar level since 2016, the first steps towards using the potential of VET more effectively were taken in the 2020s. "Social and Economic Integration through Vocational and Technical Education I and II" (SEUP I and SEUP II) and "Program for Facilitating the Access of Syrian and Host Communities to Employment through Quality Apprenticeships and Vocational Training in Turkey" (IMEP) projects have been initiated in cooperation with the MoNE and the German Development Bank (KfW). With these new projects, it is aimed to promote the integration of Syrians into the education system and the labor market.

SEUP projects are aimed to improve the infrastructure of VTAHs, which are located in provinces where Syrians are mostly populated, and to increase the access of Syrian children to VET through VTAHs. On the other side, the main focus of the IMEP is to improve the quality of apprenticeship training in VTCs rather than VTAHs. For this reason, it addresses and includes a wider group in the Syrian refugees. IMEP also includes support for the development of Turkish language skills of refugees. 
Türkiye'de Suriyeli Göçmenlerin Entegrasyonu İçin Önemli Bir İmkân: Mesleki Eğitim Üzerinden İssücü Piyasasına Erișimde Yeni Hedefler

As of 2021, a total of 13,739 Syrian students have enrolled in VET institutions: 10,835 of them in VTAHs and 2,904 of them in VTCs. The provinces with the highest number of Syrians and the number of Syrian students in VTAHs and VTCs are given in Figure 1 and Figure 2, respectively. Figure 1 shows that $85 \%$ of Syrian refugees are studying in VTAHs in the first ten provinces with the highest number of students. On the other hand, $71 \%$ of refugees are studying in VTCs in the top ten provinces with the highest number of students.

Figure 1: Top Ten Provinces with the Highest Number of Syrian Refugees in VTAHs

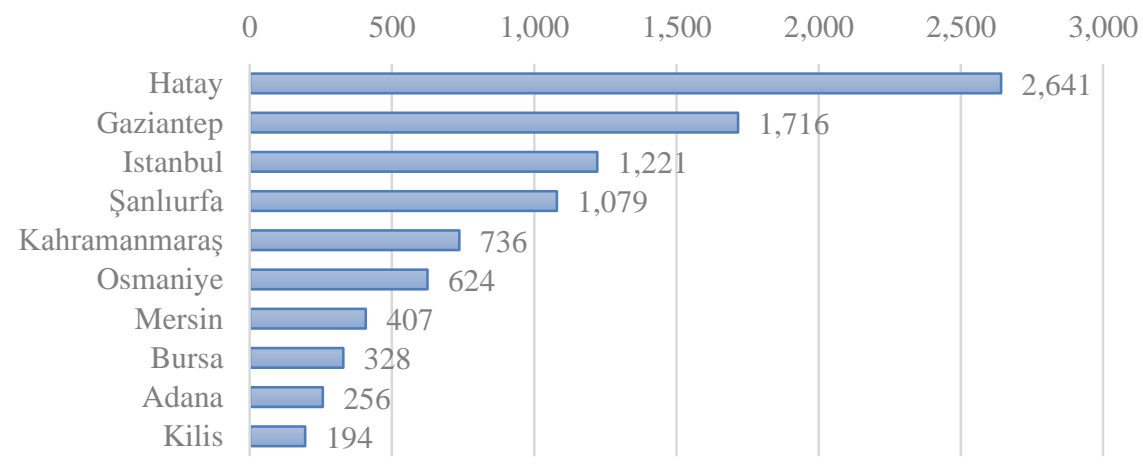

Figure 2: Top Ten Provinces with the Highest Number of Syrian Refugees in VTCs

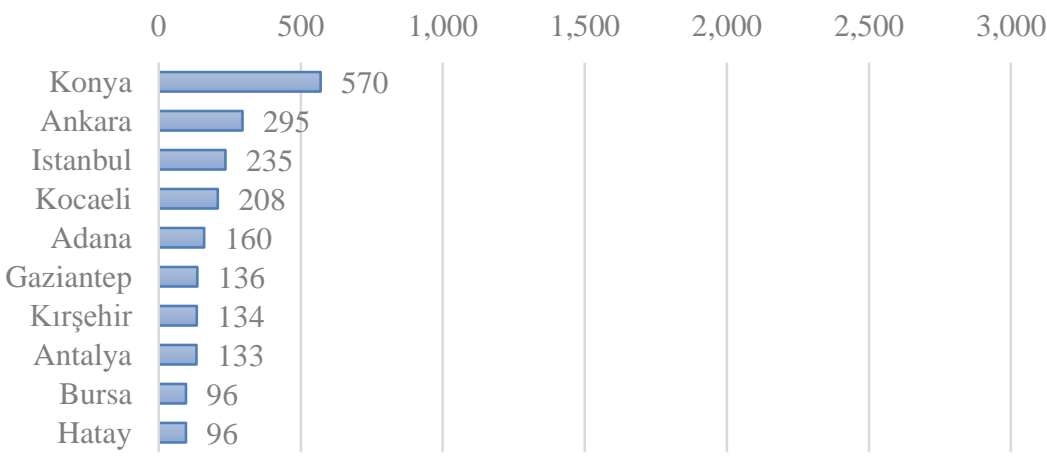

The numbers in both Figure 1 and Figure 2 show that Syrians' access to VET is extremely limited. The rate of Syrians studying at VTCs, which is more advantageous especially in transition to the labor market, to total students in VTCs is only $2 \%$. There is a need to reconsider the advantages provided by VTCs for refugees in this regard. 
Providing a wage support of at least one third of the minimum wage every month during the training at VTCs will provide significant financial support for Syrian refugees. In addition, it is an important advantage that there is no age limit to enroll in VTCs. Hence, VTCs appear to be an effective option for Syrian migrants' smooth transition to the labor market.

MoNE announced an action plan to increase Syrians' access to VTCs in an assessment meeting in April 2021. In this manner, MoNE declared that the target is to increase the rate of Syrians studying at VTCs from 2\% to $10 \%$ by the end of 2021 considering the inclusion of Syrian immigrants who are not of school age in VTCs (Anadolu Agency, 28 April 2021). For this purpose, a comprehensive study has been started in 15 provinces with the highest number of Syrians. This study aims to introduce the opportunities and advantages of VTCs for Syrian refugees in a detailed and comprehensive way. In particular, the IMEP project is intended to be used for increasing the participation of refugees in VTCs. On the other hand, active participation of local authorities in this process will be ensured through the participation of chambers of industry and commerce, local administrators and stakeholders in the selected provinces. There are successful examples of VET, especially in the provinces where Syrian refugees are highly concentrated, in cooperation with sector representatives and local actors (Siviş, 2020). These local experiences also highlight the potential of new projects of the MoNE for the refugees.

MoNE has been preparing to take another step for education and integration of refugees through VTCs. Within the scope of a new regulation, additional Turkish language support will be provided on the school days in order to support language skills of Syrian refugees in VTCs. When this regulation is put into practice, the quality of onthe-job training -which is mostly performed in companies- will also increase.

\section{Conclusion and Discussion}

Turkey is the country with the highest number of Syrian refugees since 2011 due to the civil war in Syria. Since the beginning of Syrian civil war, Turkey has made a rare sacrifice to provide comprehensive support for Syrians, from their shelter needs to their access to healthcare and education, and their transition to the labor market. The present study discusses Syrian refugees' access to VET and new projects by MoNE which facilitates Syrians' access to the labor market and supports their integration.

Turkey initially provided education services to Syrians with the expectation that the war would end and the refugees would return to their countries in a short while. Based on these expectations, the education of refugees is provided mainly in the TECs which are located in the camps and mainly with Syrian teachers based on the updated Syrian curriculum in the Arabic language. As the civil war continues and the number of Syrian migrants increases each year, permanent arrangements have been made 
Türkiye'de Suriyeli Göçmenlerin Entegrasyonu İçin Önemli Bir İmkân: Mesleki Eğitim Üzerinden İssücü Piyasasına Erișimde Yeni Hedefler

regarding the status of Syrians and their access to the available education services. Since 2016, the TECs have been closed gradually, and Syrians have been included in the Turkish education system. Many projects such as PIKTES, which provides multilevel support including Turkish language courses, have been conducted to facilitate participation of refugees in the Turkish education system.

With the contribution of this support, schooling rates of Syrians at primary and secondary education level are regularly increasing every year. However, the schooling rates decrease particularly in high school level. Many factors lead to this decrease; such as the participation in a new education system at intermediate level rather than primary level, and inadequate skills in the Turkish language (Taştan \& Çelik, 2017). These reasons behind the low schooling of Syrian refugees at high school level are beyond the scope of this study. Education is one of the key factors in refugees' socioeconomic achievement and overcoming their disadvantages in society (Koehler \& Schneider, 2019). Therefore, this study examines Syrian refugees' access to VET, which currently offers an alternative opportunity within the scope of education of immigrants.

VTCs, where on-the-job training is performed in companies four days in a week and academic education at school one day, present diverse advantages for Syrian refugees' education. Providing wage support of at least one third of the minimum wage each month during four years of education and the flexibility in enrollment age lead a great potential as an instrument for both refugees in schooling age and adults in their integration into the labor market and society. Germany has been able to make significant improvement in social integration of Syrian refugees by using this instrument as well as for other immigrants' integration into Germany in earlier periods (OECD, 2017; Stoewe, 2018; Tanrikulu, 2020). In Europe, dual VET systems, where VET is given in a company-based environment, are considered as instruments that provide effective access to stable and well-paid jobs in the labor market (Koehler \& Schneider, 2019). Integration policies of immigrants in Europe are also predominantly based on VET (Aerne \& Bonoli, 2021; CEDEFOP, 2019; Chadderton \& Edmonds, 2015).

In Turkey, the education program in VTCs is mostly similar to the dual VET system in Germany, which has been successfully implemented for years. As shown in this study, Turkey has started to take new steps to use this powerful instrument more systematically in the 2020s. Main limitation is that Syrians' access to VET is currently quite limited. It is quite significant to initiate a new policy to increase the rate of Syrians studying at VTCs from $2 \%$ to $10 \%$ by the end of 2021 . In order to achieve this goal, MoNE has planned to include different stakeholders, from administrators in provinces where Syrians are concentrated, to chambers of industry and commerce, and these collaborations are perceived as quite positive by stakeholders. In a study on VET for immigrants, it is recommended to assess the vocational skills of immigrants in their country in advance (Ereş, 2017). In this context, assessing the vocational skills they already gained in Syria, especially for adults, and arranging the VTC programs based on needs will increase the efficiency of the training process and access to VTCs. 
Although immigrants' access to VET is resisted by employers in most countries in Europe (Aerne \& Bonoli, 2021), local authorities and sector representatives in Turkey are willing for their participation in the labor market (Siviş, 2020) and this increases the feasibility and possible achievement of the projects. Making new arrangements in VTC programs in a way that would promote refugees to improve their Turkish language skills shows how seriously the MoNE approaches the problem. As the new policy succeeds, the Turkish language skills of refugees will be improved and their transition to the labor market will be much easier. The advantages of the new approach make VTCs an attractive and effective option for adult Syrian refugees, too.

\section{References}

Aerna, A. and Bonoli, G. (2021). Integration through Vocational Training. Promoting Refugees' Access to Apprenticeships in a Collective Skill Formation System. Journal of Vocational Education \& Training, doi: 10.1080 / 13636820.2021 .1894219$.

Anadolu Agency (2021, 28 April). Syrian Refugees' Access to Vocational Training Centers for Social and Economic Integration Will Be Increased https://www.aa.com.tr/tr/egitim/suriyeli-siginmacilarin-social-and-economicintegration-to be increased / 2223180

Adalı, T. and Türky1lmaz, A. S. (2020). Demographic Data on Syrians in Turkey: What Do We Know?. International Migration, 58(3), 196-219.

Bircan, T. and Sunata, U. (2015). Educational Assessment of Syrian Refugees in Turkey. Migration Letters, 12(3), 226-237.

Canbal, M. S., Kerkez, B., Suna, H. E., Numanoğlu, K. V. and Özer, M. (2020). A New Step for Paradigm Change in Vocational and Technical Secondary Education: Updating Educational Programs. Journal of Education and Humanities: Theory and Practice, 11(21), 1-26.

Cantekin, D. (2019). Syrian refugees living on the edge: Policy and practice implications for mental health and psychosocial wellbeing. International Migration, 57 (2), 200-220.

CEDEFOP (2019). Creating Lawful Opportunities for Adult Refugee Labor Market Mobility. Luxemburg: Publications Office of the European Union.

Chadderton, C. and Edmonds, C. (2015). Refugees and Access to Vocational Education and Training across Europe: A Case of Protection of White Privilege? Journal of Vocational Education \& Training, 67(2), 136-152. 

İsgücü Piyasasına Erișimde Yeni Hedefler

Del Carpio, X. V. and Wagner, M. (2015). The Impact of Syrian Refugees on the Turkish Labor Market. Policy Research Working Paper 7402, World Bank Group.

Dolapcioğlu, S. and Bolat, Y. (2019). The Education Issues of Syrian Students under Temporary Protection Status. Research in Education, doi: 10.1177 / 0034523719892019.

Emin, M. N. (2016). Education of Syrian Children in Turkey: Basic Education Policies. Ankara: SETA.

Emin, M. N. (2019). Education of Syrian Children in Turkey: Building the Future. Ankara: SETA.

Ereş, F. (2017). Problems of Immigrants who Attend Vocational Training Centers towards Vocational Courses. TÜBAV Science, 10(2), 93-101.

Hindy, L. (2018). Germany's Syrian Refugee Integration Experiment. The Century Foundation, 1919/2019.

Koehler, C. and Schneider, J. (2019). Young Refugees in Education: The Particular Challenges of School Systems in Europe. Comparative Migration Studies, 7, 28.

OECD (2017). Finding Their Way: Labor Market Integration of Refugees in Germany. Paris: OECD Publishing.

Özer, M. and Suna, H. E. (2019). Future of Vocational and Technical Education in Turkey: Solid Steps taken After Education Vision 2023. Journal of Education and Humanities, 10(20), 165-192.

Özer, M. and Suna, H. E. (2020). The Linkage between Vocational Education and Labor Market in Turkey: Employability and Skill Mismatch. Kastamonu Education Journal, 28(2), 558-569.

Özer, M., Gençoğlu, C. and Suna, H. E. (2020). Policies Implemented to Reduce Inequality in Education in Turkey. OMÜ Faculty of Education Journal, 39(2), 294-312.

Özer, M. (2020a). Vocational Education and Training as "A Friend in Need" during Coronavirus Pandemic in Turkey. Bartın University Journal of Faculty of Education, 9(2), 1-7.

Özer, M. (2020b). The Contribution of the Strengthened Capacity of Vocational Education and Training System in Turkey to the Fight against Covid-19. Journal of Higher Education, 10(2), 134-140. 
A Promising Opportunity for the Integration of Syrian Refugees in Turkey: New Targets in Accessing the Labor Market through Vocational Education and Training

Özer, M. (2020c). Educational Policy Actions by the Ministry of National Education in the Times of COVID-19 Pandemic in Turkey. Kastamonu Education Journal, 28(3), 1124-1129.

Özer, M. (2020d). Paradigm Change in Vocational Education in Turkey. Gazi University Journal of Gazi Education Faculty, 40(2), 357-384.

Özer, M. (2020e). Paradigm Change in Vocational Education: Turkey's Test with Vocational Education. Istanbul: Maltepe University Publications.

Özer, M. (2021a). New Steps taken to Strengthen Vocational Education in Turkey. International Journal of Turkish Educational Sciences, 9(16), 1-16.

Özer, M. (2021b). A New Step towards Narrowing the Achievement Gap in Turkey: "1,000 Schools in Vocational Education and Training" Project. Bartın University Journal of Faculty of Education, 10(1), 97-108.

Sarmini, I., Topçu, E. and Scharbrodt, O. (2020). Integrating Syrian Refugee Children in Turkey: The Role of Turkish Language Skills (A Case Study in Gaziantep). International Journal of Educational Research Open, 1: 100007.

Siviş, S. (2020). Integrating Bottom-Up into Top-Down: The Role of Local Actors in Labor Market Integration of Syrian Refugees in Turkey. International Migration, doi: 10.1111/imig.12775.

Suna, H. E., Tanberkan, H., Eroğlu, E., Özer, M. and Gür, B. S. (2020). Horizontal Skills Mismatch in Vocational Education in Turkey: The Reasons for out-of-field Employment. Ístanbul Üniversitesi Sosyoloji Dergisi, 40(2), 931-955.

Stoewe, K. (2018). Education Levels of Refugees: Training and Education in the Main Countries of Origin. IW-Report 37/2017. Germany: Köln.

Şimşek, D. (2019). Transnational Activities of Syrian Refugees in Turkey: Hindering or Supporting Integration. International Migration, 57(2), 268-282.

Tanrıkulu, F. (2020). Comparing of Migrants' Education Policies of Turkey and Germany. International Conference on Social Science Research ICONSR 2020, 31-40.

Taştan, C. and Çelik, Z. (2017). Türkiye'de Suriyeli Çocukların Eğitimi: Güçlükler ve Öneriler. Ankara: Eğitim-Bir-Sen Stratejik Araştırmalar Merkezi.

Tüzün, I. (2017). Türkiye'de Mülteci Çocukların Eğitim Hakkını ve Karşılıklı Uyumu Destekleyen Yaklaşımlar: Politikalar ve Uygulamalar. European Liberal Forum. 
Türkiye'de Suriyeli Göçmenlerin Entegrasyonu İçin Önemli Bir İmkân: Mesleki Eğitim Üzerinden İsgücü Piyasasina Erișimde Yeni Hedefler

Unutulmaz, K. O. (2017). Integration of Syrians: Politics of Integration in Turkey in the Face of Closing Window of Opportunity, In: D. Eroğlu-Utku, K. O. Unutulmaz and I. Sirkeci (Eds.), Turkey's Syrians: Today and Tomorrow. Transnational Press London, London.

Unutulmaz, K. O. (2019). Turkey's Education Policies towards Syrian Refugees: A Macro-Level Analysis. International Migration, 57(2), 235-252.

UNHR (2017). United Nations High Commissioner for Refugees Global Trends: Forced Displacement in 2017. UNHR, Geneva. 